\title{
ENGINE-DRIVEN ROTARY ENDODONTICS ENLARGEMENT SYSTEMS EVALUATION USING MICRO CT
}

\section{Szerzők:}

\author{
Mojtaba Mehrabanian \\ (University of Debrecen)
}

Szerző e-mail címe:

m.mehrabanian@gmail.com

\section{Lektorok:}

\author{
Juhász Alexander (PhD)
}

Debreceni Egyetem

Mező Ferenc (PhD)

Eszterházy Károly Egyetem

...és még két anonim lektor

\begin{abstract}
Absztrakt
GÉPI GYÖKÉRCSATORNA MEGMUNKÁLÓ RENDSZEREK MICRO-CT-VEL TÖRTÉNÖ VIZSGÁLATA

E szakirodalmat áttekintő tanulmány célja a különböző NiTi műszerrendszerek összehasonlítása és a gyökércsatorna morfológiai változásainak Micro-CT technika támogatásával történő számszerűsítése.
\end{abstract}

Kulcsszavak: endodontika, Micro-CT

Diszciplinák: orvostudomány

\section{Abstract}

The purpose of this literature review study was to compare the different NiTi instrumentation systems and quantifying root canal morphology changes after instrumentation with the support of the Micro-CT technique.

Keywords: endodontics, Micro-CT

Disciplines: medicine

Mojtaba Mehrabanian (2020): Engine-Driven Rotary Endodontics Enlargement SYSTEMS Evaluation Using Micro CT. Mesterséges intelligencia - interdiszciplináris folyóirat, II. évf. 2020/2. szám. 87-93. doi: 10.35406/MI.2020.2.87 
Biomechanical root canal preparation is an absolutely critical endodontic treatment step. The target is the complete removal of residual pulp tissue, bacteria, and infected dentin; as well as shaping of the root canal system. Root canal instrumentation is strongly affected by canal configuration therefore a comprehensive and profound morphology knowledge can be highly influential on the sealing efficacy and prevention of root canal aberrations (e.g., zip, elbow, perforations, and asymmetric preparation).

Since the knowledge of the root canal anatomy is essential in endodontics, many studies focus on a morphometric analysis of teeth for evaluating aspects such as the shaping ability of endodontic instruments, simulated root canal abnormalities, decalcification and sectioning techniques (Queiroz, Rovaris, Santaella, Haiter-Neto and Freitas, 2017). Moreover, several methods have been proposed to identify the canal anatomy, such as radiographies, diaphonization, computed tomography (CT), and more recently, micro-CT (Santa-Rosa, de Sousa-Neto, Versiani, Nevares, Xavier, Romeiro, Cassimiro, Leoni, de Menezes and Albuquerque, 2016).

\section{Aim of the study}

With a large number of rotary systems available on the market, clinicians need an impartial evaluation of these systems' characteristics to help them select systems to use clinically. The purpose of this literature review study was to compare the different
NiTi instrumentation systems and quantifying root canal morphology changes after instrumentation with the support of the Micro-CT technique.

\section{Micro-CT}

$\mathrm{X}$-ray microfocus computed tomography as an imaging modality has been widely utilized as a reliable methodology for the quantitative evaluation of root canal instrumentation due to its non-destructive technology that enables visualization of anatomical structures at the micrometer level (Bergmans, Van Cleynenbreugel, Wevers, and Lambrechts, 2001; Peters, Peters, Schonenberger and Barbakow, 2003). In other words, in endodontics, micro-tomography allows for qualitative and quantitative three-dimensional analyses of root canals while maintaining root integrity. Similarly, the results achieved with this modality can be as good as those obtained with histological images for endodontic analyses.

The micro-CT has been considered as the gold standard for laboratory studies in endodontics (Parekh, Shah and Joshi., 2011; Queiroz, Rovaris, Santaella, Haiter-Neto and Freitas, 2017). However, studies with upper molars showed no difference between the images obtained with micro-CT and CBCT in terms of canal detection (Domark, Hatton, Benison and Hildebolt, 2013). Furthermore, CBCT images acquired with a voxel size less than $300 \mu \mathrm{m}$ have been shown to be compatible with micro-CT images for the morphological study of hard tissues (Maret, 
Peters, Galibourg, Dumoncel, Esclassan, Kahn, Sixou and Telmon, 2014).

To characterize the efficiency of various instrumentation techniques, micro-CT based imaging studies has been used for the evaluations the following parameters: surface area change $(\Delta \mathrm{SA})$, volume change $(\Delta \mathrm{V})$, ratio of surface area change to volume change $(\Delta \mathrm{SA} / \Delta \mathrm{V})$, structure model index change $(\triangle \mathrm{SMI})$, centre of mass change (CM shift) (Juhasz., Hegedus., Marton, Benyo, Orhan., and Dobó-Nagy, 2019; Bergmans, Van Cleynenbreugel, Wevers, and Lambrechts, 2001; Hartmann, Barletta, Camargo Fontanella and Vanni, 2007; Peters, Peters, Schonenberger and Barbakow, 2003; Queiroz, Rovaris, Santaella, Haiter-Neto and Freitas, 2017).

To calculate root canal volume and surface area in micro-CT images, an image segmentation by selecting values either by visual or automatic methods is required. In a study, 31 extracted human anterior teeth were scanned by a $\mu$ CT scanner. Results showed no significant difference between visual and automatic segmentation methods regarding root canal volume measurements and root canal surface (Queiroz, Rovaris, Santaella, Haiter-Neto and Freitas, 2017).

\section{Nickel-titanium \\ rotary enlargement systems}

The application of nickel-titanium (NiTi) rotary instrumentation has not only enabled easier and faster preparation of the root canal system but has also provided consistent, predictable, and reproducible shaping with considerably less iatrogenic damage (Hulsmann, Peters and Dummer, 2005) Juhasz et al. (2019) with the help of microCT, analysed $\Delta \mathrm{SMI}$ and $\Delta \mathrm{SA} / \Delta \mathrm{V}$ parameters in straight and curved human root canals and resin simulated canal blocks subjected to ProTaper rotary enlargement. Results showed no significant $\Delta \mathrm{SMI}$ difference between tested groups whereas statistically significant $(\mathrm{p}<0.005)$ deviations in $\Delta \mathrm{SA} / \Delta \mathrm{V}$ were quantified as 1.92 and 3.22 for straight and curved human canals, respectively.

\section{Protaper Next}

ProTaper Next (PTN; Dentsply Maillefer, Ballaigues, Switzerland) is a somewhat new system. PTN instruments are made of M-wire, a special heat treated NiTi alloy that seemingly increases flexibility and resistance to cyclic fatigue. In a study supported by micro CT on twenty-four mandibular first molars, Pro'Taper Gold and Pro'Taper NEXT resulted in less transportation and greater ability to maintain furcation dentin thickness than ProTaper Universal (Gagliardi, Versiani, de Sousa-Neto, Plazas-Garzon and Basrani, 2015). Nevares et all (2016) reported success of PTN in the removal of gutta-percha obturation from severely curved canals and its chance to be used for retreatment. However, since PTN did not completely remove the obturation material; therefore, supplementary techniques are needed to improve the root canal cleaning. 


\section{Protaper Gold}

ProTaper Gold (PTG, Denstply Maillefer) presents the same geometric design of PTU files, but is more flexible due to its development with proprietary advanced metallurgy and more resistance to fatigue. Silva et all (2016) reported that PTG system has less canal transportation in the curved portion when compared to ProTaper Universal (PTU) system due to their different manufacturing processes, which evidently affect their stress-strain distribution patterns and bending behaviors, making PTG files more flexible and decreasing their tendency to straighten in curved canals.

A lot of studies have already shown that instruments that are more flexible produce more centered root canal preparations. The present results are also in harmony with a new study using micro-computed tomo-graphic imaging that showed less transportation to the PTG when compared to PTU (Gagliardi, Versiani, de Sousa-Neto, Plazas-Garzon and Basrani, 2015)

\section{Waveone (WO)}

The more recentl single-file NiTi system, WaveOne (WO) (Dentsply Maillefer, Ballaigues, Switzerland) is claimed to be able to completely prepare root canals with just one instrument. The system is planned to be used with a dedicated reciprocating motion motor (movements alternating in clockwise and counterclockwise directions), which might reduce the effect of cyclic fatigue on the $\mathrm{NiTi}$ rotary instrument, compared with rotational motion (You, Bae, Baek, Kum, Shon and Lee, 2010).

The files are made of a special NiTi alloy called memory wire that is created by an innovative thermal treatment process which also confers more instrument flexibility and greater resistance to fatigue as a big advantage (Shen, Cheung, Bian and Peng, 2006). Burklein et al (2012) have shown that root canal shaping with the WO rotary instrument can be performed with a good centering ability in regularly curved canals of extracted teeth.

In a study canal volume (CV) and surface area (SA) of 18 extracted human mandibular molars subjected to ProFile (PF), Twisted File (TF), and WaveOne (WO) nickel-titanium instrument systems were analyzed using micro-CT.

Results revealed that instrumented canals were larger and had greater surface area than uninstrumented canals. Yet, the amount of canal volume and surface area increase after instrumentation showed no significant difference (Baek, Yoo, Park, Oh, Kum, Shin andChang, 2014).

Santa et all (2016) reported no significant difference in the amount of canal transportation and shaping ability between two Single-file Systems (WaveOne and OneShape) in preparation of 10 maxillary molars with single mesiobuccal root canals with sever curvature using micro CT.

\section{Discussion}

NiTi rotary instruments have dramatically improved the quality of the cleaning and shaping of the root canals since past two 
decades. The super elasticity and shape memory of these instruments decrease the likelihood of the canal transportation along reducing valuable chairside time. Quite a lot of different brands of these instruments are available by various characteristics of the wonder NiTi alloy and also the cross-sectional shapes, cutting edges, tapering and numbers and distances of the flutes of the instruments. Currently, the single-file NiTi rotary systems such as WO is highly recommended due to saving the time for both the clinicians and the patients and improving root canal shaping quality.

In WO system, use of a glide path is not suggested by the clinical procedure flow chart given by the manufacturer that might affect the performance of WO. According to the study of Berutti et al (2012), WOreciprocating files produced less alteration in canal curvature when the glide path was established. Consequently, a glide path establishment prior to both rotary and reciprocating motion instrumentation appears to be appropriate especially in the case of curved canals.

The WO file has a different cross-sectional design along its entire active portion; the tip has a modified triangular cross-section, and the middle and neck portions of the working part of the instrument change to a neutral rake angle with a convex triangular transverse cross-section. This design of the WO system seems to increase the stiffness of files at the 5 $\mathrm{mm}$ level, resulting in its lower centering abilities despite the use of a reciprocating motion (Baek, Yoo, Park, Oh, Kum, Shin
andChang, 2014). Therefore, tip size and taper of different instruments are suggested to be carefully considered in the future studies. WO could cause more canal transportation than PF in the apical part of root canals. Consequently, glide path establishment prior to use of WO in curved canals might be beneficial.

Curved canals either natural or simulated in resin blocks have been traditionally used to evaluate the aspects of the shaping ability, including canal transportation and centering ability of different NiTi systems. However, a major limitation of most of proposed evaluation methods is the need of operator intervention. Therefore, developing of root transportation analysis with an automatic approach measuring the entire simulated canal without operator intervention is highly recommended in future studies.

In several studies, acrylic blocks have been used to analyze the quality and safety of different instrumentation systems (Juhasz., Hegedus., Marton, Benyo, Orhan., and DobóNagy, 2019; Silva, Muniz, Pires, Belladonna, Neves, Souza and De-Deus, 2016). The use of resin blocks in this study enabled standardization of root canal anatomy, such as angle, curvature radius, diameter and length of the root canal. Therefore, this technique allows a reduction of variations during the instrumentation procedures. However, resin blocks present different properties when compared to human teeth, as they do not provide information about remaining dentin thickness after root canal preparation (MaiaFilho, Rizzi, Coelho, Santos, Costa, Carvalho, 
et al, 2015). As a result, studies based on acrylic blocks specimen should be combined with analysis of the shaping ability of enlargement systems in human teeth (Yun and Kim, 2003).

\section{References}

Baek, J., Yoo, H., Park, D. S., Oh, T., Kum, K-Y., Shin, S. and Chang, S. (2014). Comparison of the shaping abilities of three nickel-titanium instrumentation systems using micro-CT. Journal of dental sciences. 9. 111-117. doi: 10.1016/i.jds.2013.12.002.

Berutti E, Paolino DS, Chiandussi G, et al. (2012): Root canal anatomy preservation of WaveOne reciprocating files with or without glide path. J Endod 2012;38:101-4. Burklein, S., Hinschitza, K., Dammaschke, T. and Schafer, E. (2012): Shaping ability and cleaning effectiveness of two single-file systems in severely curved root canals of extracted teeth: Reciproc and WaveOne versus Mtwo and ProTaper. Int Endod J 2012;45: 449-61.

Domark, J.D., Hatton, J.F., Benison, R.P. and Hildebolt, C.F. (2013): An ex vivo comparison of digital radiography and cone-beam and micro computed tomography in the detection of the number of canals in the mesiobuccal roots of maxillary molars. $J$ Endod. 2013;39(7):901-5

Gagliardi, J., Versiani, M. A., de Sousa-Neto, M. D., Plazas-Garzon, A., and Basrani, B.
(2015). Evaluation of the Shaping Characteristics of ProTaper Gold, Pro'Taper NEXT, and Pro'Taper Universal in Curved Canals. Journal of Endodontics, 41(10), 1718

1724. doi: $10.1016 /$ j.joen.2015.07.009

Hulsmann, M., Peters, O.A., Dummer, P.M.H. (2005): Mechanical preparation of root canals: shaping goals, techniques and means. Endod Topics 2005;10:30-76.

Juhasz, A., Hegedus, C., Marton, I., Benyo, B., Orhan, K., and Dobó-Nagy, C. (2019). Effectiveness of Parameters in Quantifying Root Canal Morphology Change after Instrumentation with the Aid of a Microcomputed Tomography. BioMed research international, 2019, $9758176 . \quad$ doi: $\underline{10.1155 / 2019 / 9758176}$

Bergmans, L., Van Cleynenbreugel, J., Wevers, M. and Lambrechts, P. (2001): A methodology for quantitative evaluation of root canal instrumentation using microcomputed tomography. International Endodontic Journal, vol. 34, no. 5, pp. 390398, 2001.

Hartmann, M.S., Barletta, F. B., Camargo Fontanella, V. R. and Vanni, J. R. (2007): Canal transportation after root canal instrumentation: a comparative study with computed tomography. Journal of Endodontics, vol. 33, no. 8, pp. 962-965, 2007.

Maia-Filho, E.M., Rizzi, C.C., Coelho, M.B., Santos, S.F., Costa, L.M.O., Carvalho, C.C., et al. (2015): Shaping ability of reciproc, unicone, and protaperuniversal in 
simulated root canals. Scientific World J. 2015; 2015:1-6.

Maret, D., Peters, O.A., Galibourg, A., Dumoncel, J., Esclassan, R., Kahn, J.L., Sixou, M. and Telmon N. (2014): Comparison of the accuracy of 3dimensional cone-beam computed tomography and microcomputed tomography reconstruc-tions by using different voxel sizes. J Endod. 2014;40(9):1321-6.

Nevares, G., de Albuquerque, D. S., Freire, L. G., Romeiro, K., Fogel, H. M., dos Santos, M., and Cunha, R. S. (2016). Efficacy of ProTaper NEXT Compared with Reciproc in Removing Obturation Material from Severely Curved Root Canals: A Micro-Computed Tomography Study. Journal of Endodontics, 42(5), 803808. doi:

\subsection{6/i.joen.2016.02.010}

Peters, O. A., Peters, C. I., Schonenberger, K. and F. Barbakow (2003): ProTaper rotary root canal preparation: effects of canal anatomy on final shape analysed by micro CT. International Endodontic Journal, vol. 36, no. 2, pp. 86-92, 2003.

Parekh, V., Shah, N., Joshi, H. (2011): Root canal morphology and variations of mandibular premolars by clearing technique: an in vitro study. J Contemp Dent Pract. 2011;12(4):318-21.

Queiroz, P. M., Rovaris, K., Santaella, G. M., Haiter-Neto, F. and Freitas, D. Q. (2017). Comparison of automatic and visual methods used for image segmentation in
Endodontics: a microCT study. Journal of Applied Oral Science,25(6),674-679. doi: 10.1590/1678-7757-2017-0023

Santa-Rosa, J., de Sousa-Neto, M. D., Versiani, M. A., Nevares, G., Xavier, F., Romeiro, K., Cassimiro, M., Leoni, G. B., de Menezes, R. F., and Albuquerque, D. (2016): Shaping Ability of Single-file Systems with Different Movements: A Micro-computed Tomographic Study. Iranian endodontic journal, 11(3), 228-233. doi: 10.7508/iej.2016.03.016

Shen Y, Cheung GS, Bian Z, Peng B. (2006): Comparison of defects in ProFile and ProTaper systems after clinical use. J Endod 2006; 32:61-5.

Silva, E. J., Muniz, B. L., Pires, F., Belladonna, F. G., Neves, A. A., Souza, E. M., \& DeDeus, G. (2016): Comparison of canal transportation in simulated curved canals prepared with ProTaper Universal and ProTaper Gold systems. Restorative dentistry \& endodontics, 41(1), 1-5. doi: 10.5395/rde.2016.41.1.1

You, S.Y., Bae, K.S., Baek, S.H., Kum, K.Y., Shon, W.J. and Lee W. (2010): Lifespan of one nickeletitanium rotary file with reciprocating motion in curved root canals. J Endod 2010;36:1991-4.

Yun, H., Kim, S.K.. (2003): A comparison of the shaping abilities of 4 nickeltitanium rotary instruments in simulated root canals. Oral Surg Oral Med Oral Pathol Oral Radiol Endod. 2003; 95(2): 228-33. 